This item was submitted to Loughborough's Research Repository by the author.

Items in Figshare are protected by copyright, with all rights reserved, unless otherwise indicated.

\title{
Rapid manufacturing - impact on supply chain methodologies and practice
}

PLEASE CITE THE PUBLISHED VERSION

PUBLISHER

(C) Inderscience

VERSION

AM (Accepted Manuscript)

LICENCE

CC BY-NC-ND 4.0

REPOSITORY RECORD

Tuck, Christopher, Richard J.M. Hague, and Neil D. Burns. 2019. "Rapid Manufacturing - Impact on Supply Chain Methodologies and Practice". figshare. https://hdl.handle.net/2134/5657. 
This item was submitted to Loughborough's Institutional Repository (https://dspace.lboro.ac.uk/) by the author and is made available under the following Creative Commons Licence conditions.

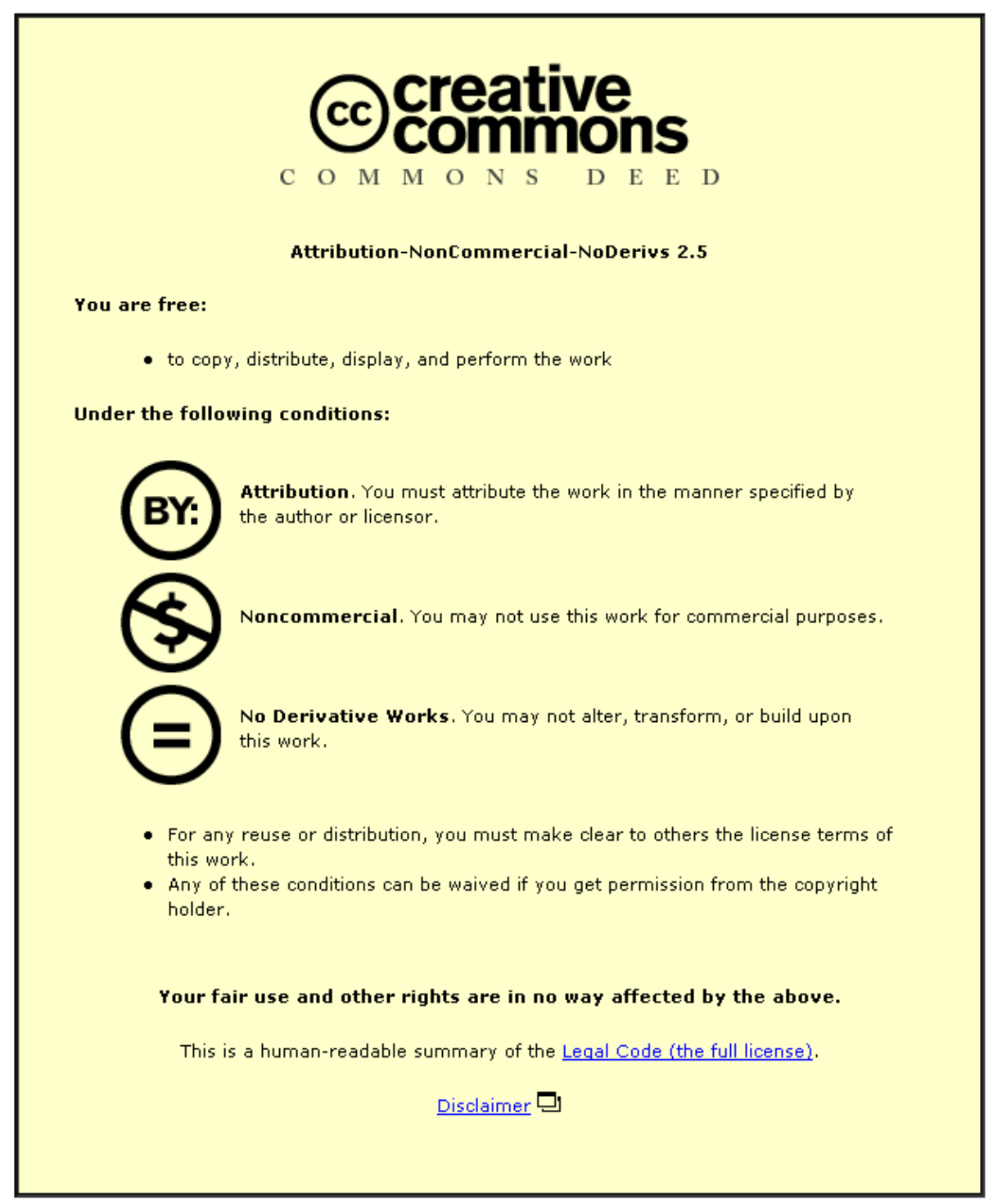

For the full text of this licence, please go to: http://creativecommons.org/licenses/by-nc-nd/2.5/ 


\section{Rapid Manufacturing - Impact on Supply Chain Methodologies and Practice}

\section{Abstract}

This paper demonstrates the use of Rapid Manufacturing (RM) as the enabling technology for flexible manufacturing in a number of industrial sectors. The paper discusses the evolution of Rapid Prototyping (RP) to Rapid Manufacturing and the current issues that require further research for the successful integration of this technology within manufacturing companies. The use of RM will have particular impact on supply chain management paradigms such as lean and agile and has particular strategic fit with mass customisation. The effect RM will have on these paradigms is discussed and confirmed with example cases from automotive production, motor sport and medical devices industries. In conclusion RM has already been shown in the three cases to offer benefits, particularly where fast re-configuration of the manufacturing process is required and with the production of customised components.

\section{Introduction}

Rapid Manufacturing (RM) is evolving from Rapid Prototyping (RP) technologies that have been successfully used to physically visualise designs and concepts. Rapid Manufacturing is concerned with the direct manufacture of parts and components using additive manufacturing techniques (Hague et al., 2003, Hopkinson and Dickens, 2001 and Rooks, 2002). The techniques have some important advantages that are linked to the technology's modus operandi. The concept of additive manufacture requires that components be constructed from data files derived from three dimensional (3D) Computer Aided Design (CAD) software and are manufactured by adding material together. This is in contrast to more traditional subtractive manufacture where material is removed through processes such as machining (Griffiths, 2002).

Advantages of additive manufacture lie in the ability to produce highly complex parts that require no tooling and thus reduce the costs of manufacture, especially for low volumes 
(Hopkinson and Dickens 2001, Griffiths 2002). As high volumes do not need to be manufactured to offset the cost of tooling then the possibilities for affordable, highly complex, custom parts becomes apparent. In theory, each part that is produced could be a custom part.

With all new and novel technological developments, some questions have yet to be answered and these questions form the principle drivers for the uptake of RM as a manufacturing process. Some of the questions are based on implications on design methods and practices (Hague et al. 2003), process and materials improvement (Hague et al., 2004), and business implications of RM (Halliday and Hague 2002). It is with the latter subject that this paper is concerned.

This paper has been written as part of a United Kingdom Department of Trade and Industry (DTI) Foresight Vehicle funded research project entitled "Management, Organisation and Implementation of Rapid Manufacturing" (ManRM). The ManRM project aims to provide a foundation of knowledge with respect to the application of RM in current and future manufacturing environments.

It must be stated that current RM is being done on RP systems such as laser sintering (LS) or stereolithography (SL). However, though the machines have improved considerably over the past ten years, these systems require further development for full scale manufacturing, such as:

1. The machines have been designed for prototyping and are therefore relatively slow, inaccurate and give poor surface finish.

2. The cost of materials and machines is prohibitive.

3. Materials selection is limited to a few polymeric, metallic and ceramic materials. 
4. The materials available have little information available with regard to their true engineering characteristics.

As the parts are produced additively, stair stepping can be noticeable, though changing build orientation can reduce this. These aspects, coupled with specific build envelopes that limit the size of the components, mean that current RP systems are not yet optimised for RM.

However, a number of companies are undoubtedly performing RM with current RP methods today. The production of individually tailored orthodontics has proven a successful business model for Invisalign (Invisalign, 2005). Customised orthodontics are designed and then moulds built using stereolithography from which "invisible" teeth aligners are then produced. The manufacturing of custom designed hearing aids has been developed by Phonak Hearing Systems and Siemens Hearing Solutions (Hopkinson et al. 2005). This has resulted in the use of RP equipment and materials to produce fully customised in-the-ear devices. Along with other cases, these examples serve to demonstrate that RM has a bright future in the manufacturing of products and services.

Of particular consideration is the effect that RM could have on supply chain management thinking. The work presented here will outline some of the key changes that are likely and their impact on current supply chain methodologies. This is backed up with three examples of current RM applications, including, automotive component and medical devices manufacture.

\section{Literature Review - Supply Chains}

It is important to define what the supply chain is and why it is so important to all businesses. The network of suppliers that are involved in providing products or services can be defined as members of the "supply chain". This may include raw materials suppliers, sub-assembly, 
information systems, logistics, retailers and finally the customer. Supply chain management as defined by Slack et al. (1998) is concerned with the holistic management of the supply chain as a whole. Cox (1999a) outlined the research agenda necessary to develop supply chains in terms of a strategic and business importance. A key objective for businesses developing and researching their supply chain management practices is to:

"appropriate value for themselves from their participation in the supply chain."

What is clear from Cox's paper is that not all supply chain methods and practices are suitable for every company. Indeed, companies that might benchmark themselves to successful innovators of supply chain thinking can often do more harm than good in their own enterprise. The differentiation in supply chain practice should be developed from analysing the firm's business practices and the properties of demand for its products. In the development of suitable supply chain practices for the appropriation of value, a number of supply chain concepts have been developed. These include:

- Lean

- Agile

- Leagility and Postponement

- Mass Customisation

- Demand chain

These concepts have been used as a basis for arguments that will become applicable on the successful realisation of RM and are discussed in more detail below.

\subsection{The Lean Paradigm}

The lean paradigm of supply chain management encompasses the idea of reducing waste throughout the supply chain. In further work by Cox (Cox 1999b) a summary of the eight lean supply chain characteristics was given. These include: 
TITLE

1. Perfection in delivering value to customers

2. Produce only when necessary and concentrate on the creation of value

3. Eliminate waste in all operational processes, both internal and external

4. All members of the supply chain must be able to appropriate value

5. Trusting relationships are necessary rather than adversarial ones

6. Co-operate with suppliers to create lean and demand driven logistics processes

7. Reduce the number of suppliers to those preferred for long-term relationships

8. Create a supplier network that understands the waste reducing principles of the lean paradigm

These general characteristics can be achieved through different methods. For example, a popular methodology for eliminating waste in stock holding and time would be to introduce a Just-In-Time delivery schedule with suppliers (Slack et al., 1998). These initiatives require the development of long term relationships with suppliers as it would be difficult to instigate these changes in supply methods that influence the entire companies operations without a trusting relationship. However, the lean paradigm relies on some fundamental market principles for it to be effective in a given market. These principles (Fisher, 1997) are concerned with aspects of demand choices and demand patterns. The lean paradigm should suit products that have the following attributes:

- Long product lifecycle

- Low margin

- Low product variety

- Accurate forecasting of demand

- Market order winner is cost

Unpredictable demand can have drastic effects on upstream suppliers; one such effect, "Bullwhip", was first identified by Forrester (1961). In principle the bullwhip effect stems from 
consumer demand patterns where fluctuations in demand are magnified down the supply chain (upstream) with increasing volatility (Mason-Jones et al., 2000, Towill, 1997 and Forrester, 1961). However, this effect can be minimised through the selection of a complimentary supply chain methodology for different types of product. The difference in products and therefore customers has been clearly explained by Fisher (1997). A supply chain methodology selection matrix is shown in Figure 1. For commodity products that have a stable demand profile, the use of an efficient supply chain and thus, those that reduce waste, will be more effective. However, a second paradigm exists in order to cater for more innovative products with shorter product lifecycles - the agile paradigm.

\subsection{The Agile Paradigm}

Naylor has defined the term agility in his discussion of lean, agile and leagile supply chains (Naylor et al. 1999),

"Agility means using market knowledge and a virtual corporation to exploit profitable opportunities in a volatile market place."

Agility focuses on lead time compression, rather than the elimination of waste. The use of flexible production methods allows fast reconfiguration of processes to cope with consumer demand. For this reason, the agile paradigm is suited to products that have a short lifecycle, such as fashionable goods, compared with lean's focus on commodity production. Therefore the market order winner for agile supply chains is no longer cost but availability. Referring to Figure 1, the agile paradigm is a responsive supply chain that suits innovative products.

It could be said that the advent of the agile supply chain has been necessary because of the increased demands of the customer being placed on the producer (Maskell, 2001). The sophistication of customer desires and tastes has led to goods becoming increasingly fashion 
TITLE

oriented with styles and colours becoming a market order winner rather than product function. One methodology for enabling this "value-adding" activity has been the concept of mass customisation (Pine II, 1993). The ability to define a customer's needs and wants relies on the availability of suitable information on customer preferences and the ability within the agile organisation to provide these services in a timely manner. Thus, the emphasis on production has changed from one based on costs of production to knowledge and information availability and hence, the skills and knowledge of the organisation are now paramount (Maskell 2001).

One area of particular importance for the agile paradigm is that of the build to order (BTO) or make to order (MTO) supply chain, recently reported by Kathawala and Wilgen (2005). Kathawala and Wilgen (2005) discuss the use of build-to-order supply chains (BOSC) and the evolution of manufacturing operations to facilitate the implementation of agile processes; cases have been given where BOSC have been implemented (Dell and BMW). Kathawala and Wilgen (2005) conclude that the BOSC developed by the case companies will not be suitable for all industries and customers. In fact the use of BOSC requires the re-organisation of the company in order create a system able to deal with fluctuating demand and consumer differences. Hybrids of the BOSC have been adopted, BMW uses a locate to order strategy that is an initial step towards BOSC.

Storey et al. (2005) present work on the barrier that a customer responsive (agile) supply chain has using data from Marks and Spencer. They argue that there has been a need to move beyond the lean philosophy and reduce the lead time between the manufacturer and the consumer. The paper presents conclusions that, although the development of an agile supply chain where minimal stock outs, obsolescence and response to fluctuations in demand is possible, a number of difficulties exist. The difficulties surround collaborative relationships between suppliers and retailers and managerial acceptance at the highest level. 


\subsection{Leagility and Postponement}

The concept of leagility brings together the concepts of lean and agile supply chains in order to appropriate greater value from the supply chain. The leagile paradigm aims to develop the lean supply chain (with it's efficient practises) into an organisation where it would be possible to take these cost advantages and use them to gain market share in more volatile markets, normally served by agile supply chain management practices. The defining attributes of lean and agile products are presented in Table I.

The development of leagile supply chains has been discussed by a number of authors (Naylor et al., 1999, Childerhouse and Towill, 2000 and van Hoek, 2000). In order to produce an effective leagile supply chain the lean and agile supply methods must be integrated to produce a supply chain that can provide down-stream (towards the customer) responsiveness and upstream stability. This can be achieved through postponement (van Hoek, 2001).

In a leagile supply chain the application of a de-coupling point allows the two systems to be integrated and defines when and where to implement lean or agile practices. This de-coupling point removes the down-stream volatility of customer demand and acts as a buffer to those processes up-stream; postponement delays certain activities within the supply chain until the customer order has been received. The delay can be used to postpone the addition of value to a product until the order has been received and therefore reduce costs of stockholding by providing a generic platform that can be manipulated to any future customer order. This also has the added advantage of reducing obsolescence of stock and increasing levels of responsiveness when customer orders are received. This can lead to a competitive advantage where, through the reduction in costs and increased response to customer demands, the market is better served. 


\subsection{Mass Customisation}

As mentioned previously, consumers are becoming increasingly refined in their tastes and desires for products. But what is customisation? In order to discuss any type of customisation a definition is required. The Cambridge on-line dictionary defines "customise" as:

"to make or change something according to the buyer's or user's needs"

The ability to meet customer requirements has resulted in a new paradigm in manufacturing; that of mass customisation.

The production of low cost and high variety products has become a necessity in many product areas. Mass customisation is used in order to differentiate products and add significant value to the consumer by producing products that satisfy the consumer's need for individualisation. It is perhaps now difficult to envisage a world where "you can have any colour as long as it is black" (Henry Ford quoted in Pine II, 1993) would be an acceptable phrase.

The impact of mass customisation on the production environment has been profound. As mentioned previously, mass customisation could be thought of as a key driver for the agile supply chain paradigm's prominence in manufacturing business thinking worldwide. The use of mass customisation can be seen in many of today's products. For example, electronics equipment such as PCs and mobile phones (Dell and Nokia X-Press On ${ }^{\text {TM }}$ covers, respectively). However, of particular concern to the ManRM project is mass customisation that has been focused on the automotive sector. In order to create value and compete with lowercost imported vehicles, western manufacturers have found it necessary first to change their operational model to compete with Far East suppliers and secondly, to seek competitive advantage in the area of mass customisation. 
Work has been carried out into the concept of mass customisation in the context of the vehicle manufacturing industry (Alford et al. 2000). In this paper the focus was on optional customisation of high volume manufacturing. Alford et al. (2000) define three strategies for customisation in the automotive sector; these being:

- Core - Direct customer involvement in the design process of the vehicle. This method of customisation requires a low volume product due to the nature of the manufacturing processes possible and the interaction of the customer.

- Optional - Focused on high volume manufacture of vehicles where the purchaser chooses customised "options". These options can then be integrated into the vehicle during assembly.

- Form - The concept of form customisation is to change the form of the standard product at the distributor for example, changing the finance package, service and warranty specifications.

These three customisation strategies have defining characteristics. Each requires different properties in the manufacturing process (such as, low, medium or high volume) or require different perceptions from the customer as to what customisation really is.

The definitive aim for customisation of a vehicle should surely be that based on core customisation, whereby the customer specifies the vehicle in such a way that the vehicle meets their needs completely. As mentioned previously, this could only occur currently with low volume goods as the knowledge and skills to produce such a product are not easily transferable to a mass production environment. For these reasons, cost effective core customisation of vehicles is not currently a reality for the majority of consumers. 
TITLE

\section{Research Question and Methodology}

The use of RM for the production of end-use parts is, as stated previously, in its infancy. The development of RM will inevitably result in changes to the supply chain and ultimately the operations that support that supply chain. Many questions exist as to how RM will change these paradigms that arise from the modus operandi of the technology for example, labour requirements, logistics and time to market will all be affected. This paper aims to provide a foundation for discussion on how RM will change supply chain management thinking.

After reviewing the literature on supply chain management paradigms the possible impacts of RM on those paradigms are discussed and validated through examples of RM that occurs in industry today. The case studies presented show how RM has enabled the production of components giving specific advantage to the company in question. These advantages will be outlined and compared to existing supply chain literature for confirmation of the affect of RM on supply chain methodologies and practice. Particular reference to how the use of RM can enable agile and customised manufacturing systems is given.

\section{The Impact of RM}

Having defined the current state of the art in supply chain management principles, it is possible to discuss the possible impact of RM on these management paradigms and possible consequences. The impact of RM on supply chain practices could be the most profound, as it not only impinges on current methodologies but also on the constituent parts of the supply chain.

\subsection{Impact of RM on the Lean Supply Chain}

As mentioned in Section 2.1, the lean manufacturing paradigm relies on some fundamental operators for successful implementation. Those 8 characteristics discussed in Cox (1998) 
provide the backbone to the lean methodology. Taking some of these points in turn, it is possible to distinguish what effect RM could have. RM will affect the "mechanics" of the lean methodology and as such RM will influence the production of parts when necessary through JIT methods and the elimination of waste in the supply chain. These two topics are discussed in the following two sections.

\subsubsection{Produce only when necessary, through Just-In-Time}

The application of RM techniques will hold a number of advantages for JIT manufacture, which include:

- Dematerialised supply chain - The overriding requirement for RM is to have suitable 3D CAD data from which to produce the part or product. This will have consequences upon the supply chain as it will be said that the supply chain is becoming dematerialised.

- True Just-In-Time - As the RM machine requires only 3D CAD data and raw material in order to produce the part, the application of RM in the manufacturing environment will result in a reduction of material distribution and stock holding or warehousing costs for work in progress (WIP). The ability to amalgamate RM with Internet technology and other manufacturing systems (MRP etc.) will lead to JIT manufacture at the factory, rather than the traditional concept of JIT delivery to the firm.

- Reduced set up, changeover time and number of assemblies - It must be stressed that the production of parts through RM will change the manufacturing paradigm from that of skilled labour operating machinery and forming a large portion of part cost, to one where the burden of cost is transferred to the technology or specifically the RM machine and materials. A further driver for the reduction of costs is in the product design. For example, RM processes may make traditional designs obsolete, by reducing the need for assemblies and thus the production process may provide cost savings for parts and components (Hague et al. 2003). 
As RM requires no tooling changes to produce different parts or products, time that is traditionally lost to these factors will be reduced and hence a second element of the lean paradigm will be addressed; the elimination of waste.

\subsubsection{Elimination of Waste}

A principle driver for the lean paradigm is to reduce waste wherever possible in the supply chain. The effect that RM will have on this area will be especially significant, if arguments about the digital supply chain (Fralix, 2003) are taken into account. Integration with Internet technology will result in the fast exchange of data between designers and manufacturers, where in the case of RM, this data can be sent directly to the RM system for build.

The application of RM as mentioned in Section 1, allows the economic production of single parts. For this reason, what would be the need to hold stock, if, as will be possible with RM, they can be produced, on time every time to the product design specification? As such, the only stock that might need to be held is that in the design and no value added raw material. The production of parts to order quickly and economically will result in no part stock holding unless this is desired for reasons of agility and the component is more functional than innovative (Fisher, 1997).

It is possible to take the concept of RM in the lean supply chain further. If production is reliable and does not result in stock penalties, can production be brought back in house? For example, could production of parts and components occur next to an assembly line? What implications would this have on the supply chain? Primarily this will have a drastic effect on the cost of logistics. It may no longer be necessary to ship goods, either internationally or nationally. 
These drivers will affect the costs of production and thus allow supply chains practising lean methodologies to further reduce waste.

The factors discussed above will result in the elimination of waste in terms of:

- Material

- Time

- Costs

- Distribution

\subsection{Impact on the Agile Supply Chain}

As discussed in Section 2.2, the agile supply chain works best for volatile products, such as those that are fashionable or have a short product lifecycle. The advent of RM will mean that lean production in a responsive manner will become a reality without the need for a "leagile" concept.

In effect RM would become the de-coupling point with orders only pulled off at the request of the customer. With this concept, there would be no stock outs, as all products can be produced to order, plus the threat of obsolescent stock would be negated as the only stock necessary to hold would be raw material and design data. Taking Marshall Fisher's $2 \times 2$ matrix as seen in Figure 1, this can be modified to take into account the application of RM technology and its possible fit into supply chain management. The current mis-match that exists with an efficient supply chain and an innovative product can be removed using RM techniques, thus providing an innovative product with a lean and efficient supply chain mechanism. This is shown in Figure 2.

In summary, RM will offer: 
TITLE

- Truly "leagile" supply chain

- Low cost products with fast re-configurability and fast response

- Reduction in stock levels

- Reduced waste

- Increased value

- Reduced logistics cost

- Reduction in part count

- Increased flexibility

The effect of RM on inventory has been identified by Walter et al. (2002). The application of RM for suitable parts and components especially those that are of low volume but high value can result in a significant reduction in stock costs and inventory levels. The ability to produce components to order is an inherent quality associated with RM. As such the parts or products required can be stored as low value raw materials and the stock value is reduced to that of the raw material and any obsolescence risks associated with the part or product design are eliminated.

As Rapid Manufacturing has a low labour requirement, implications on the manufacturing location will occur. The ability to produce RM parts locally will also have implications on the current globalisation culture of manufacturing business.

As mentioned previously, the overriding cost for RM production is not labour, but the machines and materials necessary for production. Indeed Walter et al. (2002) have stated that a single operator is able to efficiently manage several machines. For this reason, the migration of manufacturing operations to low-wage countries can be challenged especially for low volume and customised products and with the advent of more capable machinery, high volume products in the long term. 


\subsection{Impact of RM on Mass Customisation}

The area of customisation discussed in section 2.5 was generally concerned with the concept of mass customisation (Pine II, 1993). As discussed, this method uses standard products as a base for customisation of certain characteristics of the product allowing added value to be attributed to a product. But how can this be improved, and what role will RM play?

Considering the core customisation concept described by Alford et al. (2000), where the customer has intimate involvement with the vehicle in production and design, RM will have an important role. The automobile industry offers numerous options on their products from colour of bodywork to seat fabric, and the finance deal that the customer is offered. These are not considered as core customisation and in an article by Fox (2003), it was suggested that core customisation of cars was not yet possible. But, taking into account the advantages of RM, this may now be possible (Loch et al. 2003). The ability to produce complex structures from digital data taken from or designed with the customer will easily be manufactured and used on that customer's vehicle. Rapid Manufacturing can offer true core customisation on two levels.

1. Aesthetic Customisation - The first level of customisation would be that based on customer preference, this may be to improve the aesthetics of parts or components to the customer's specification.

2. Body-fit Customisation - The second level, involves the customer more intimately, by digitally capturing the customer's body shape it will be possible to provide the customer with body fit parts, for example, customised seat and seat back, to provide a more comfortable environment.

The production of body fit parts and core customisation is not novel, however, the process of design and production would involve a great deal of skill in the production of the parts and hence a large expense. With the advent of RM, the production method and processes involved 
TITLE

for customised parts would not change from part to part. Thus, the economic argument for providing this core customisation method can be improved.

\subsection{Impact of RM on Demand Logistics}

An example of how RM can affect the distribution of goods and services was postulated by Walter et al. (2002), by considering the aerospace spare parts business. The supply chain for some aerospace components was too slow and the demand too unpredictable to continue with the supply chain practices used; as such, Rapid Manufacturing methods were sought and evaluated. Walter et al. (2002) go on to discuss the possibilities of reducing stock holding and logistics for slow moving aerospace spare parts. Two scenarios were considered. Firstly, the centralised production of components to replace inventory, and secondly, a decentralised set of RM units to replace inventory and some of the conventional distribution network.

Taking the first premise, Walter et al. (2002) saw benefits in the cost of holding stock for slow moving items that would otherwise be subsidised from more popular, faster moving items. The second distribution scenario was thought to be suitable only when demand is high enough at a given location.

\section{Examples of Current RM}

Current examples of RM are based on RP equipment; nonetheless this is still RM. Companies are operating $\mathrm{RM}$ in order to benefit from the advantages of discussed in this paper. Three cases are now presented which specifically use RM for different purposes. The first two cases are based in the automotive sector, the third in the medical arena. A brief description of the three cases follows. 


\subsection{Case 1 - Automotive Component}

An automotive manufacturer during the final stages of development of a new product discovered a design problem that required solving before launch of the product was possible. A suitable component was designed using 3D CAD to solve the issue; a traditional manufacturing method (injection moulding) was envisaged for the component. However, the time for manufacturing the injection moulding tool (6 weeks) would have resulted in delayed launch for the product. In order to launch the product on time, RM was utilised to resolve the problem, internal RP equipment (LS) was used to manufacture a buffer of parts before the first batch of IM components were received. The resultant parts were qualified for use with necessary durability tests and were found to perform as required.

\subsection{Case 2 - Renault F1}

An article by Kochan (2003) has outlined the current use of RP equipment for RM at Renault F1. The equipment was used for the manufacture of scale model wind tunnel parts and enduse parts for race cars. In the first 5 months of 2003 the machines built over 2000 parts for wind tunnel testing. Due to the nature of these aerodynamic tests, many of these parts are incrementally different, thus in effect every part is individual.

\subsection{Case 3 - Hearing Aid Industry}

The third case further outlines the benefits of RM in the manufacture of In-The-Ear (ITE) hearing aid devices by Siemens Hearing Solutions (2003) and Phonak (2003). The ITE device is a particular challenge to these companies as the packaging area is cramped and in order to achieve the required performance from the instrument a tight seal with the ear is essential. Additionally, cosmetics are very important for the user and as such the device should look as natural as possible. In order to accomplish the necessary cosmetic and fitting requirements a 
TITLE

customisation approach has been taken where the ITE devices are now individually customised to the user's ear.

\subsection{Discussion}

Each case operates in a very different market. Case 1 produces automotive vehicles at medium to high volumes for sale to the consumer. Case 2 operates in the Formula 1 arena and as such a highly competitive sector where development of the race car is of paramount importance, i.e. improved performance on the track equals increased revenue. Case 3 produces hearing devices for the consumer; comfort and quality are key market levers. A summary of the strategic reasons for using RM are shown in Table I.

The chosen cases each show how RM can impact on different business and operational models and SCM paradigms to benefit the organisation. Using the arguments developed in section 4 as a basis for discussion, the impact of RM can be illustrated and how RM influences the organisation's supply chain. A comparison of these results is presented outlining the different qualities of RM for these organisations. Where the cases do not specifically refer to the SCM factor in question other examples from the literature have been used to illustrate the impact of RM in this case.

\subsubsection{Lean}

The application of RM for the fulfilment of lean principles in an organisation has been demonstrated by the three cases presented. Taking each of the factors discussed in section 4.1 with illustration from the cases it is possible to see the possible impact that RM can have on this SCM paradigm. The eight characteristics discussed by Cox 1999b have been affected by the introduction of RM in these organisations. Case 1 in particular highlights the ability of RM to impact the lean SCM paradigm. Through the use of RM, the time pressures due to an 
engineering issue were solved. This consequently highlighted the ability of RM as a production method to influence the four criteria seen above. A summary of the effect of RM on lean criteria for case 1 now follows:

Produce only when necessary through JIT - The component was produced as to requirements of the production schedule. The 1800 components built were produced in 6 batched of 300 at a production time of 8 hours per batch.

Dematerialised supply chain - An intrinsic quality of the RM production system is the necessity of digital data and raw materials for production. The use of digital data means that the systems are ideal for developing a dematerialised supply chain, where components are produced with little to no work in progress. In this specific case the data produced by the designer was sent directly to the RM machine operators and then placed upon the bed for manufacture.

Reduced set up, changeover time and number of assemblies - Again an intrinsic quality of RM, case 1, as mentioned previously, used an existing prototyping facility within the organisation to produce the parts in question. In order to begin production the only set up that was required was to fill the LS machine with raw material and place the digital data on the "virtual" bed of the machine. Therefore changeover time was minimal. In addition, after the first batch had been set up, subsequent batches require less time to set as the "build" file can be saved along with the 3D CAD data for use in the future. This case has not shown the reduction of the number of assemblies with the use of $\mathrm{RM}$, however, examples of this exist in other industries. Wohlers, 2005, has presented how RM can be used to rationalise the number of assemblies in a product, specifically, the development of a single part by On-DemandManufacture (ODM) for Boeing. The use of RM and innovative design reduced an air ducting component from an assembly of 10 components to a single piece that could be produced using LS. 
TITLE

Elimination of waste - The waste eliminated in Case 1 revolved around the reduction in time for the component to be delivered to the manufacturing organisation. The use of RM for the component reduced the waiting time of the initial batch of components from 6 weeks to 8 hours. The total production of RM components during this 6 week period resulted in a total of 1800 components. The use of RM saved each of these vehicles (900 in total) $£ 40$ due to the delays for traditional manufacturing resulting in a company saving of $£ 36,000$. In addition to this cost saving, distribution costs were minimised as the components were produced on site.

\subsubsection{Agile}

The impact of RM for an agile supply chain has been demonstrated by case 2. Kochan, 2003 shows how RP (though arguably it is RM) has been exploited at Renault F1 as a flexible manufacturing system. The business model for Renault F1 is very different to that shown in case 1 , as their prime focus is on speed of vehicle development to gain fractions of a second on the racetrack. The wind tunnel facility that the RM systems support tests 30-40 new aerodynamic designs per day on $50 \%$ scale models. Traditionally the components would have been produced by model makers from carbon fibre.

The reasons for utilising RM in case 2 are two-fold: Firstly, each component required by the wind tunnel is unique, i.e. the components are incrementally different. The fact that each component is different means that traditional manufacturing methods such as injection moulding would be unsuitable as the cost of tooling would be prohibitive. The second reason for utilising RM is that traditionally, wind tunnel parts were manufactured by laminating a machined mould with carbon fibre. This consumed both labour and capacity on existing machining facilities, which reduced the time available for race car production. Renault F1 is able to offer a service to their designers and wind tunnel facility that ensures time is not taken from essential race car manufacturing equipment. Indeed a $24 \mathrm{hr}$ turnaround time from receipt 
of CAD data at the facility to having the part ready for testing has been quoted. In addition to this it is also possible to have another 30 different variations of the component being built at the same time. The use of RM has meant that Renault F1 has increased the number of designs made and tested by a factor of 10 .

The products produced by RM at Renault F1 show the key characteristics of the agile products as described by Mason-Jones et al. 2000 (Table I). The components have high variety, are innovative and have a short product lifecycle. The availability of these components at the correct time is key to the future of the business.

In addition to the production of test components, RM is also now being used for the production of race car components. The parts in question are lightly stressed components such as complex air ducting components and parts for the electrical system (Goode, 2003). Additionally, the demands of each race circuit are quite different; as such the RM components are able to be optimised for each race without expensive tooling changes. The move to RM has also had implications on operations at Renault, due to the low labour content of RM production the machines are able to run $24 \mathrm{hrs}$ a day 7 days a week. However, the facility operates over a normal working week (8:30 am - 6:30 pm, Monday to Friday) with systems in place to inform operatives in the event of a breakdown or build completion. Using the criteria for agile manufacturing set out in section 4.2 the impact of RM on the agile paradigm outlining the attribute shown by case 2 in comparison to traditional manufacturing methods can be summarised.

Low cost products with fast re-configurability and fast response - As with case 1 the RM system is able to be reconfigured for each different build through the addition or subtraction of components to the "virtual" build area. The response of this set up and re-configurability is limited only to the speed of the operator and software at placing the components. Traditionally 
TITLE

these components would have required newly machined mould patterns (taking up time from race car component production) and subsequent mould production and lamination.

Reduced stock levels - The stock levels of components have not changed as the components are individual and only used for testing their lifetime is very short. However, if a component requires reproduction it is only necessary to find the requisite $3 D$ CAD data for production. In comparison to traditional methods the storage of the original moulding would be required and thus in effect the use of RM has reduced the stock levels of physical components at the factory. Reduced waste - Waste has been reduced in various forms when compared to the original manufacturing operation. Firstly the removal of moulds has been possible; in addition the removal of labour for carbon fibre lamination has meant that this skilled labour can be moved to the race car. Time that was previously required for the machining of patterns on race car production equipment has been removed releasing capacity for manufacture of chassis components.

Increased value - Labour has been able to be moved from the production of test components to the value adding activities of race car production and component design.

Reduced logistics cost - The use of RM in case 2 has resulted in the reduction of mould tools in the production of components for the test facility. Therefore storage of these mould tools is no longer required and existing designs are now stored virtually (as the 3D CAD file).

Reduced part count - Part count reduction has also been possible in specific instances, for example radiator test components have been consolidated from an assembly of 5 items to a single part.

Increased flexibility - The use of RM in case 2 has resulted in an increase in the number of components tested by the wind tunnel $(\times 10)$ and in addition production of a greater number of variants (50-100 variants of every component tested in the wind tunnel). Additionally race car components have been able to be produced where the mechanical demands have been met by the RM process. 
This is truly agile manufacturing as the RM systems produce individual parts not only from build to build but also in the same batch of components.

\subsubsection{Mass Customisation}

Case 3 has been identified as a suitable demonstration of how RM can be utilised for the production of mass customised components. In many ways the case echoes case 2 . The production of customised hearing aids requires the same agility and flexibility within the business as that shown by case 2 , in fact for the demonstration of an agile paradigm the two are interchangeable. However, where case 3 differs is in the production of body fitting customised components. Case 3 has exploited recent advances in 3D scanning techniques and RM and developed these into a new business concept.

Using 3D scan data taken from the moulded impression the detail of the ear canal can be exported to suitable software, manipulated and a final CAD model produced for manufacturing. In addition to getting the form of the shell correct for a good fit, articles such as ventilation holes and receiver holes are added during the CAD phase. RM techniques are then used to build the individual ITE devices from biocompatible materials; usually stereolithography resins (Hopkinson et al. 2005). Previously, this was done by taking a deep impression of the ear and then moulding a hollow shell from the impression. However, problems exist with this method, for example manual finishing of the product can result in a badly fitting device or the impression of the ear may not provide all necessary information. The production of these devices was dependent on the skill of operatives, both in taking a suitable impression and finishing the final shell. In terms of the company's operations the move to RM has significant benefits:

1. Tooling has been eliminated

2. Labour has been reduced in manufacture and finishing 
3. Weekend or overnight production possible without increased labour

4. Lower cost product with increased quality

These benefits all stem from the ability to take 3D CAD data and reproduce this directly in an RM machine. Wohlers (2005) has reported on the hearing aid industry being a great proponent of RM and quotes that Siemens Hearing Solutions had sold more than 150,000 units to mid year 2003 at a rate of 2000 products per week. This surely demonstrates that RM (even with RP equipment) is a viable manufacturing technique and offers company's savings in terms of waste reduction. In addition, the application of RM in this area proves the effective use of RM as a tool for customisation and mass customised products, offering both advantages for the manufacturer and the user of the component. Referring to Alford et al. (2000), though the product is not based in the automotive sector; it does demonstrate the use of RM for core customisation, i.e. intrinsically linked to the customer's wants and needs. The development of RM as a flexible manufacturing has direct influence on the agile and lean paradigms discussed. With particular reference to Anderson and Pine (1997) agile manufacturing capability is one of the key process infrastructures that is needed for mass customisation.

Table III provides a summary of the three cases and their impact on the criteria laid out in section 4 and discussed here. Each of the cases demonstrates some if not all of the characteristics required by the SCM paradigms presented by previous authors.

\section{Conclusions}

In conclusion, this paper has outlined some of the effects on supply chain methodologies and principles that will occur with the advent of Rapid Manufacturing. Three supply chain management principles of lean, agile and leagile supply as well as the aspect of mass customisation were considered. 
It is clear that RM has the potential to change or modify these paradigms greatly. The opportunities available for reduction in costs of production, through the natural rationalisation of logistics, labour, stock holding and the ability to deal with unstable demand patterns are all apparent. The ability to remove these costs could also affect the manufacturing environment on a global scale, by returning manufacturing to the country of origin, as labour costs are no longer a burden. Rapid Manufacturing could also realise the first truly flexible and JIT supply chain paradigm, that can respond to customer demand and changes in taste and design with ease.

Additionally, the introduction of Rapid Manufacturing could lead to increased value in products through the realisation of truly customised production. The ability to produce innovative customised products through an efficient and responsive supply chain could mean both increases in overall market share for organisations and increased satisfaction for the consumer.

The impact on manufacturing will be the most profound. Rapid Manufacturing will change design leading to a reduction in both the number of components necessary for assemblies and a reduction in waste, whether this be time or cost.

The ability to produce part and products locally will have profound affects on the lead times and costs of these parts, brought about partly through the removal of inventory costs and a reduced cost of distribution. Indeed, no longer will it be necessary to produce parts cheaply thousands of miles away; for low volume and custom products, they could be produced for less, in a more convenient location.

Multiple RM machinery can currently be operated by a single operator, thus reducing the demands placed on the labour force, and consequently, bringing manufacturing back from low 
TITLE

wage economies. Thus the economies of the global work place could be replaced by the economies of technology.

The RM cases discussed highlight many of the advantages that are hoped will become mainstream as RM evolves. The automotive case outlines the advantages of RM in terms of speed to market (reduced by one month compared to traditional production) and the subsequent improvement in stock levels (i.e. products can be sold earlier). Again the leagility of the process is born out as no changes in skills or tooling are necessary to build different parts and changeover times are eliminated.

Renault F1 are currently using RP as a manufacturing method this allows them to produce low volume (custom) components efficiently (24/7) with a low labour requirement. RM offers the flexibility of producing thousands of individual components from a 3D CAD data source for wind tunnel testing, and the production of highly complex structures for race cars.

The case of the hearing aid industry serves to show the reduction in manufacturing operations for a complex customised component that benefits, in terms operations management, from reduced labour, reduced waste (finishing) and greater flexibility of production (i.e. a greater number of production hours per week) are possible.

Though many questions remain to be answered on how the development of RM and full customisation can be implemented, the impact of this technology on the manufacturing and consumer environment will be immense.

\section{References}

Alford D., Sackett P. and Nelder G. (2000) "Mass customisation - an automotive perspective" International Journal of Production Economics, Vol 65, pp. 99-110. 
Anderson D.M. and Pine II B.J. (1997) "Agile Product Development for Mass Customization", Chicago, Irwin Professional Publishing.

Childerhouse B. and Towill D. (2000) "Engineering supply chains to match customer requirements" Logistics Information Management, Vol 13, No 6, pp. 337-345.

Cox A. (1999a) "A research agenda for supply chain and business management thinking" Supply Chain Management: An International Journal, Vol 4, No 4, pp. 201-211

Cox A. (1999b) "Power, value and supply chain management" Supply Chain Management: An International Journal, Vol. 4, No 4, pp.167-175.

Fisher M. (1997) "What is the right supply chain for your product?" Harvard Business Review, Vol. 75, No 2, pp.105 - 116

Forrester J.W. "Industrial Dynamics" MIT Press, 1962, Boston, MA

Fox S. (2003) "Recognising materials power" Manufacturing Engineer, April.

Fralix M. (2003) "The realities behind the myths of mass customisation" Mass Customisation and Personalisation Conference, Munich, October.

Griffiths A. (2002) "Rapid Manufacturing - the next industrial revolution" Materials World, Vol 10, No 12, pp. 34-35.

Goode E. (2004) "3D Systems Announces the Installation of SLS Systems at Renault F1 Team Advanced Digital Manufacturing Centre" last accessed January 2005.

website:

http://www.3dsystems.com/newsevents/newsreleases/pdfs/041304_3D_Systems_Announces_ and_Renault_F1_ADMC.pdf

Halliday I. and Hague R. (2002) "The Management of Rapid Manufacturing" Proceedings of Time Compression Technologies Conference, Manchester

Hague R., Campbell I. and Dickens P. (2003) "Implications on design of Rapid Manufacturing" Proceedings of the Institution of Mechanical Engineers Part C: Journal of Mechanical Engineering Science, Vol 217, pp. 25 -30.

Hague, R.J.M., Mansour S. Saleh N., and Harris R. (2004) "Materials Analysis of Stereolithography Resins for use in Rapid Manufacturing" Journal of Materials Science, Vol 39, pp.2457-2464.

Hopkinson N. and Dickens P. (2001) "Rapid prototyping for direct manufacture" Rapid Prototyping Journal, Vol 7, No 4, pp 197 - 202

Hopkinson, N, Hague R.J.M., and Dickens P. (2005) "Rapid Manufacturing: An Industrial Revolution for the Digital Age" $1^{\text {st }}$ Edition, John Wiley \& Sons, ISBN 0-470-01613-2

Invisalign, 2003, website: www.invisalign.com 
TITLE

Kathawala Y. and Wilgen A. (2005) "The evolution of build-to-order supply chain and its implications with selected cases" International Journal of Services Operations Management Vol.1, No. 3, pp. 268 - 282

Kochan A. (2003) "Rapid Prototyping Helps Renault F1 team UK Improve Championship Prospects", Assembly Automation, Vol 23, No 4, pp 336 - 339

Loch, Sommer, Schafer and Nellassen (2003) "Will Rapid Manufacturing bring us the customised car?" Automotive World Knowledge.

Mason - Jones R., Naylor B. and Towill D. R. (2000) "Engineering the leagile supply chain" International Journal of Agile Management Systems, Vol 2, No 1, pp. 54 - 61

Maskell B. (2001) "The age of agile manufacturing" Supply Chain Management: An International Journal, Vol 6, No1, pp. 5-11

Naylor J.B., Naim M.M. and Berry D., "Leagility: Integrating the lean and agile manufacturing paradigms in the total supply chain" International Journal of Production Economics, Vol 62, 1999, pp. $107-118$.

Pine II J. (1993) "Mass Customisation - The new frontier in business competition" Harvard Business School Press, Boston, MA

Rajagopalan S., Pinilla J.M., Losleben P., Tian Q. and Gupta S.K. (1998) "Integrated design and Rapid Manufacturing over the Internet" Proceedings of DETC98 Atlanta

Renault F1, 2003, website:

http://www.renaultf1.com/en/poweredby/team/partners/3dsystems/news.php?name=en/news/p _7121.html

Rooks B. (2002) "Rapid Manufacturing advances at Loughborough" Assembly Automation, Vol 22, No 4, pp. 333-336

Slack, Chambers, Harland, Harrison, and Johnson (1998) "Operations Management" $2^{\text {nd }}$ Edition, Pitman Publishing, pp. 474.

Storey J, Emberson C, Reade D, "The barriers to customer responsive supply chain management" International Journal of Operations and Production Management, Vol 25, No. 3, 2005, pp. 242-260

Van Hoek R. I. (2000) "The thesis of leagility revisited" International Journal of Agile Management Systems, Vol 2, No 3, pp. 196 - 201.

Van Hoek R. I. (2001) "The rediscovery of postponement a literature review and directions for research" Journal of Operations Management, Vol 19, pp. 161 - 184

Walter M., Holmström J., Tuomi J. (2001) "Rapid Manufacturing and its impact on supply chain management:

"http://www.tai.hut.fi/ecomlog/publications/rapid_manufacturing.pdf 
Williams T., Maull R. and Ellis B. (2002) "Demand chain management theory: constraints and development from global aerospace supply webs" Journal of Operations Management, Vol 20, pp. 691-706

Wohlers T. (2003), http://www.pma-magazine.com/articles/2003/october/4

Wohlers T (2005), "Wohlers Report 2005: Rapid Prototyping, Tooling \& Manufacturing State of the Industry Annual Worldwide Progress Report" Wohlers Associates. 


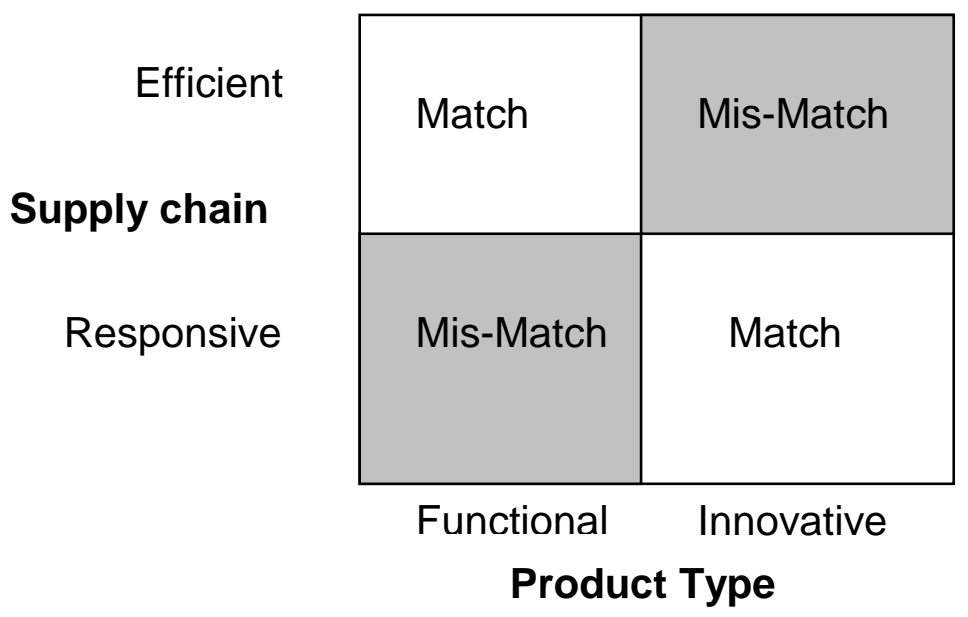

Figure 1. Product, supply chain matrix (Source: Fisher 1997)

\begin{tabular}{|l|c|c|}
\hline \multicolumn{1}{|c|}{ Distinguishing Attributes } & Lean Supply & Agile Supply \\
\hline Typical products & Commodities & Innovative \\
\hline Market place demand & Predictable & Volatile \\
\hline Product variety & Low & High \\
\hline Product lifecycle & Long & Short \\
\hline Customer drivers & Cost & Availability \\
\hline Profit margin & Low & High \\
\hline Dominant costs & Physical costs & Marketability costs \\
\hline Stock out penalties & Long term contractual & Immediate and volatile \\
\hline Purchasing policy & Buy goods & Assign capacity \\
\hline Information enrichment & Highly desirable & Obligatory \\
\hline Forecasting mechanism & Algorithmic & Consultative \\
\hline
\end{tabular}

Table I. A comparison of lean and agile supply chain operators (Source: Mason-Jones et al. 2000)

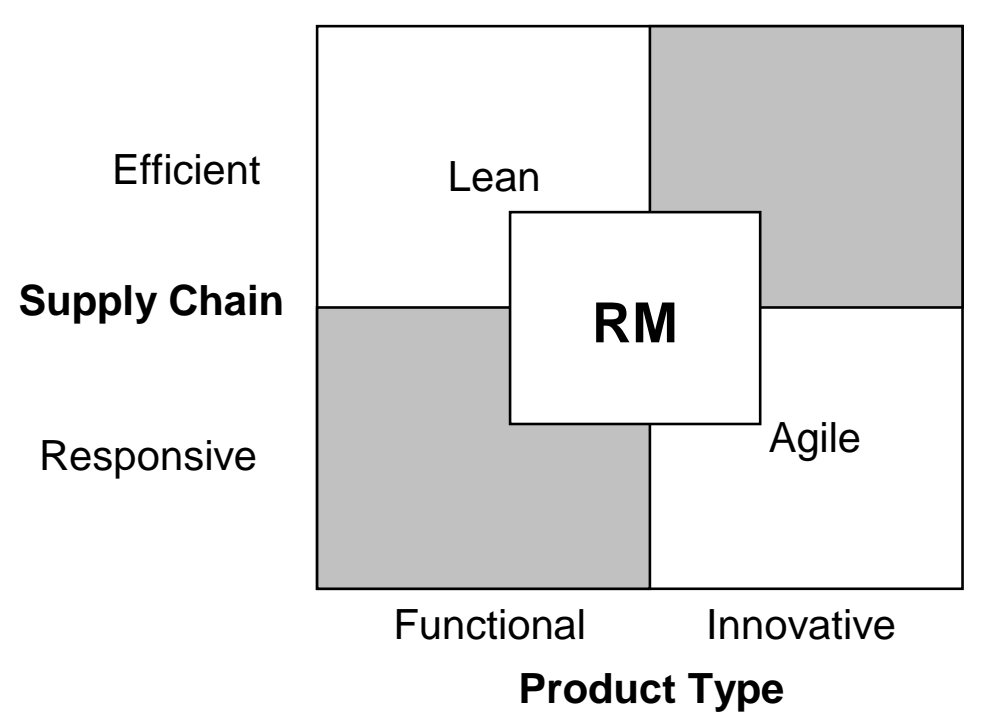

Figure 2. Modified production and supply chain matrix. 


\begin{tabular}{|c|c|c|}
\hline Case 1 & \multicolumn{2}{|c|}{ Case 2 } \\
$\begin{array}{c}\text { Use of RM to provide interim } \\
\text { production solution and } \\
\text { reduce costs of a vehicle }\end{array}$ & $\begin{array}{c}\text { RM used to provide } \\
\text { increased capacity of } \\
\text { individual products for wind } \\
\text { tunnel testing }\end{array}$ & $\begin{array}{c}\text { Coupled with 3D scanning } \\
\text { methods, mass } \\
\text { customisation of ITE devices } \\
\text { for individual customers }\end{array}$ \\
\hline
\end{tabular}

Table II. Strategic reasons for using RM for individual cases. 


\begin{tabular}{|c|c|c|c|c|}
\hline $\begin{array}{l}\text { Supply Chain } \\
\text { Paradigm }\end{array}$ & Impact Factor & CASE 1 & CASE 2 & CASE 3 \\
\hline \multirow{8}{*}{ Lean } & Just In Time & Demonstrated & Possible & Possible \\
\hline & $\begin{array}{l}\text { Dematerialised } \\
\text { Supply Chain }\end{array}$ & $\begin{array}{l}\text { Yes, 3D CAD file } \\
\text { and Raw materials } \\
\text { only }\end{array}$ & $\begin{array}{l}\text { Yes, 3D CAD file } \\
\text { and Raw materials } \\
\text { only }\end{array}$ & $\begin{array}{l}\text { Yes, 3D CAD file and } \\
\text { Raw materials only }\end{array}$ \\
\hline & $\begin{array}{l}\text { Reduced Setup } \\
\text { and Changeover } \\
\text { Time }\end{array}$ & $\begin{array}{l}\text { No changeover or } \\
\text { changes to set up } \\
\text { required for different } \\
\text { components }\end{array}$ & $\begin{array}{l}\text { No changeover or } \\
\text { changes to set up } \\
\text { required for different } \\
\text { components }\end{array}$ & $\begin{array}{l}\text { No changeover or } \\
\text { changes to set up } \\
\text { required for different } \\
\text { components }\end{array}$ \\
\hline & Reduced Waste & $\begin{array}{l}\text { All } 1800 \\
\text { components built } \\
\text { were used }\end{array}$ & $\begin{array}{l}\text { Reduced Labour } \\
\text { content, tooling, } \\
\text { increase capacity for } \\
\text { wind tunnel and race } \\
\text { car production }\end{array}$ & $\begin{array}{l}\text { Reduced labour } \\
\text { content, tooling } \\
\text { eliminated }\end{array}$ \\
\hline & Reduced Time & $\begin{array}{l}\text { Time saving of } 6 \\
\text { weeks }\end{array}$ & $\begin{array}{l}\text { Fast turnaround of } \\
\text { parts. } \\
\text { Increased number of } \\
\text { test component s by } \\
\text { factor of } 10\end{array}$ & $\mathrm{~N} / \mathrm{A}$ \\
\hline & $\begin{array}{l}\text { Reduced } \\
\text { Material }\end{array}$ & $\mathrm{N} / \mathrm{A}$ & N/A & N/A \\
\hline & Reduced Costs & $\begin{array}{l}\text { Cost saving of } £ 40 \\
\text { per vehicle }\end{array}$ & N/A & $\begin{array}{l}\text { Costs of production } \\
\text { reduced due to labour } \\
\text { and tooling elimination }\end{array}$ \\
\hline & $\begin{array}{l}\text { Reduced } \\
\text { Distribution }\end{array}$ & $\begin{array}{l}\text { In-house production } \\
\text { - distribution costs } \\
\text { minimised }\end{array}$ & $\begin{array}{l}\text { Distribution costs } \\
\text { have not changed }\end{array}$ & $\begin{array}{l}\text { Distribution costs } \\
\text { have not changed }\end{array}$ \\
\hline \multirow{7}{*}{ Agile } & $\begin{array}{l}\text { Reduced Stock } \\
\text { Levels }\end{array}$ & $\begin{array}{l}\text { Batches of } 300 \text { parts } \\
\text { built to order }\end{array}$ & $\begin{array}{l}\text { Tooling stock } \\
\text { eliminated }\end{array}$ & $\begin{array}{l}\text { Tooling stock } \\
\text { eliminated }\end{array}$ \\
\hline & Reduced Waste & $\begin{array}{l}\text { Reduced waiting } \\
\text { time for components } \\
\text { and considerable } \\
\text { cost saving } \\
(£ 36,000) \text { over } 900 \\
\text { vehicles }\end{array}$ & $\begin{array}{l}\text { Production capacity } \\
\text { increased for race } \\
\text { car chassis, labour } \\
\text { reduced in part } \\
\text { manufacture }\end{array}$ & $\begin{array}{l}\text { Labour reduced in } \\
\text { tooling production. }\end{array}$ \\
\hline & Increased Value & $\begin{array}{l}\text { Vehicle availability } \\
\text { and quality improved }\end{array}$ & $\begin{array}{l}\text { Testing regime } \\
\text { improved, more time } \\
\text { to spend in design } \\
\text { and testing rather } \\
\text { than production }\end{array}$ & $\begin{array}{l}\text { Production schedule } \\
\text { has been streamlined, } \\
\text { improving availability }\end{array}$ \\
\hline & $\begin{array}{l}\text { Reduced } \\
\text { Logistics }\end{array}$ & $\begin{array}{l}\text { Logistics in } \\
\text { comparison to } \\
\text { traditional } \\
\text { manufacturing have } \\
\text { reduced }\end{array}$ & N/A & $\mathrm{N} / \mathrm{A}$ \\
\hline & $\begin{array}{l}\text { Reduced Part } \\
\text { Count }\end{array}$ & No & $\begin{array}{l}\text { Demonstrated by } \\
\text { radiator case }\end{array}$ & No \\
\hline & $\begin{array}{l}\text { Increased } \\
\text { Flexibility }\end{array}$ & Yes & Yes & Yes \\
\hline & $\begin{array}{l}\text { Low Cost and } \\
\text { Fast } \\
\text { Reconfigurability }\end{array}$ & $\begin{array}{l}\text { Fast re- } \\
\text { configurability } \\
\text { demonstrated }\end{array}$ & $\begin{array}{l}\text { Lower cost than } \\
\text { traditional } \\
\text { manufacturing, fast } \\
\text { re-configurability } \\
\text { demonstrated }\end{array}$ & $\begin{array}{l}\text { Lower cost than } \\
\text { traditional } \\
\text { manufacturing, fast re- } \\
\text { configurability } \\
\text { demonstrated }\end{array}$ \\
\hline \multirow{2}{*}{$\begin{array}{c}\text { Mass } \\
\text { Customisation }\end{array}$} & Aesthetic & $\mathrm{N} / \mathrm{A}$ & N/A & Not Desired \\
\hline & Body Fitting & $\mathrm{N} / \mathrm{A}$ & N/A & Demonstrated \\
\hline
\end{tabular}

Table III. Table of Components and Cases versus characteristics of Lean and Agile and MC 